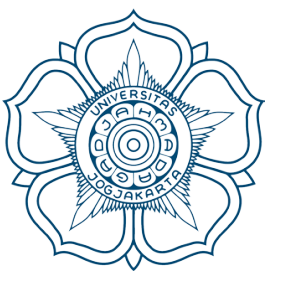

Judul Naskah : PEMILIHAN KONSEP PERATURAN PERPAJAKAN UNTUKMENANGGULANGIDAMPAKASYNCHRONOUS INFORMATION DALAM TRANSAKSI ELEKTRONIK DI INDONESIA

Nama Penulis : Anugrah Anditya

MIMBAR HUKUM

$\begin{array}{ll}\text { DOI } & : \text { http://doi.org/10.22146/jmh.29138 } \\ \text { Penerbit } & : \text { Fakultas Hukum Universitas Gadjah Mada } \\ \text { URL } & : \text { jurnal.ugm.ac.id/jmh } \\ \text { E Issn } & : 2443-0994 \\ \text { P Issn } & : 0852-100 \mathrm{x}\end{array}$




\title{
PEMILIHAN KONSEP PERATURAN PERPAJAKAN UNTUK MENANGGULANGI DAMPAK ASYNCHRONOUS INFORMATION DALAM TRANSAKSI ELEKTRONIK DI INDONESIA*
}

\author{
Anugrah Anditya** \\ Hukum Pajak dan Hukum Teknologi, Fakultas Hukum, Universitas Gadjah Mada \\ Jalan Sosio Yustisia No. 1 Bulaksumur, D.I. Yogyakarta 55281
}

\section{Abstract}

Potential lost from taxation in Indonesia which came from an electronic transaction could happen due to asynchronous information between authority and tax payer. In electronic transacsions, the authority have no information as much as the taxpayer or party which directly involved during electronic transations. To overcome this condition Indonesia needs concept in exchange of information regarding taxation partuclarly in actual electronic transactions. Consideration for the concept to be chosen will include such as legal characteristic of current regulation and taxation reporting system for electronic transaction Indonesia.

Keywords: concept, electronic commerce, tax, .

\section{Intisari}

Potensi kehilangan pemasukan pajak di Indonesia yang berasal dari transaksi elektronik dapat terjadi karena adanya asynchronous information antara fiskus dan wajib pajak. Dalam transaksi elektronik fiskus tidak akan memilki informasi sebanyak yang dimiliki oleh pihak yang terlibat langsung dalam transaksi tersebut. Untuk menangani keadaan tersebut Indonesia memerlukan konsep pertukaran informasi yang akan digunakan dalam peraturan perpajakan dengan melihat keadaan saat ini. Pertimbangan dalam pemilihan konsep adalah karakteristik peraturan dan sistem pelaporan perpajakan yang timbul atas transaksi elektronik.

Kata Kunci: konsep, transaksi elektronik, pajak.

\section{Pokok Muatan}

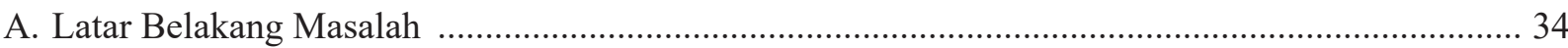

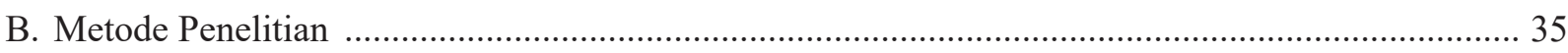

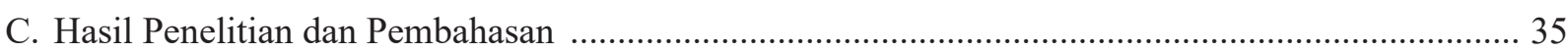

1. Pengaturan Pertukaran Informasi dalam Kebijakan Perpajakan di Indonesia ............................ 35

2. Instrumen Hukum Ideal yang Diperlukan oleh Fiskus untuk Mengatasi Asynchronous

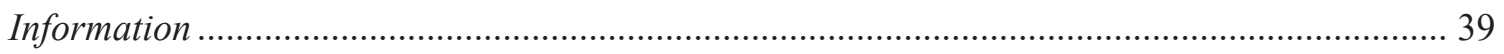

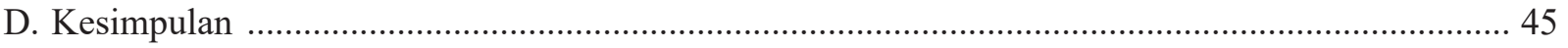

Hasil penelitian didanai Fakultas Hukum UGM 2017

Alamat korespondensi: anugrah.anditya@ugm.ac.id. 


\section{A. Latar Belakang Masalah}

Indonesia sebagai negara dengan jumlah pengguna internet peringkat 6 di dunia merupakan pasar yang potensial dalam perdagangan elektronik dengan jumlah pengguna internet yang mencapai 132 juta pengguna pada tahun 2016. ${ }^{1}$ Potensi keuntungan yang dapat diperoleh dari transaksi elektronik dapat mencapai 250 triliun rupiah dan diproyeksikan akan mencapai 1.625 triliun rupiah pada tahun $2020 .^{2}$ Dengan jumlah dan pertumbuhan yang tinggi tersebut maka dapat dikatakan bahwa nantinya perdagangan elektronik merupakan sektor yang potensial dalam meningkatkan jumlah penerimaan dari perpajakan.

Transaksi elektronik sebagai suatu kegiatan di bidang ekonomi terkait erat dengan aspek perpajakan, khususnya pajak penghasilan dan pajak pertambahan nilai. Dua jenis pajak tersebut merupakan pajak yang mungkin timbul dalam transaksi elektronik sebagaimana jenis pajak yang lazim terjadi dalam perdagangan secara konvensional. Dalam kerangka transaksi elektronik, maka pajak penghasilan timbul karena pihak yang melakukan penjualan atau dalam hal ini disebut sebagai penjual mendapatkan tambahan kemampuan ekonomi dikarenakan menerima pembayaran yang dibayarkan oleh pembeli, sedangkan pajak pertambahan nilai dapat terjadi apabila barang yang diserahkan merupakan barang kena pajak dan para pihak yang terlibat dalam transaksi tersebut termasuk sebagai pengusaha kena pajak atau yang diperlakukan sama dengannya.

Perdagangan secara elektronik memiliki kendala tersendiri bagi fiskus dalam hal melakukan identifikasi terhadap suatu transaksi yang sekiranya menimbulkan utang pajak. Permasalahan tersebut timbul karena adanya asynchronous information antara fiskus dan wajib pajak. Kejelasan informasi antara fiskus dan wajib pajak mengenai suatu transaksi apakah menimbulkan utang pajak atau bahkan mulai dari sudah terjadi transaksi elektronik atau belum tidak sama antar para pihak.

Berdasarkan penjelasan sebelumnya maka dapat diperjelas lagi bahwa asynchronous information merupakan suatu keadaan dimana terdapat perbedaan informasi yang diperoleh oleh para pihak. Dalam transaksi elektronik khususnya antara fiskus dan wajib pajak terdapat perbedaan yang signifikan karena dalam peristiwa tersebut wajib pajak merupakan pihak yang secara langsung terlibat dalam perbuatan yang dapat menimbulkan utang pajak, sedangkan fiskus dalam hal ini hanya menerima informasi yang berasal dari pelaku wajib pajak pelaku transaksi elektronik atau dapat dikatakan informasi mengenai peristiwa yang sama (transaksi elektronik) antara fiskus dan wajib pajak dapat berbeda.

Asynchronous information dapat berdampak pada pemasukan yang berasal dari pajak, dengan adanya perbedaan informasi tersebut maka wajib pajak memiliki peluang yang besar untuk melakukan penghindaran pajak. ${ }^{3}$ Hal tersebut dapat terjadi karena fiskus tidak memiliki informasi yang sebanding dengan informasi yang dimiliki oleh wajib pajak dan tanpa adanya informasi yang cukup maka fiskus tidak akan memiliki landasan yang kuat untuk melakukan penagihan terhadap wajib pajak tersebut.

Potensi kehilangan pemasukan pajak yang berasal dari transaksi elektronik dapat terjadi apabila asynchronous information antara fiskus dan wajib pajak tetap dibiarkan dan tidak dilakukan mitigasi yang tepat. Hal tersebut mengingat untuk dapat memberikan kepastian bagi fiskus untuk melakukan pemungutan dan penagihan pajak maka fiskus harus memiliki informasi yang akurat ${ }^{4}$ terkait dengan

Pada Tahun 2016, Pengguna Internet di Indonesia Capai 132 Juta., Lebih lengkap baca Kompas, "Pengguna Internet di Indonesia Capai 132 juta”, http://tekno.kompas.com/read/2016/10/24/15064727/2016.pengguna.internet.di.indonesia.capai.132.juta., diakses pada 1 April 2017.

Kemendag, 2016, Kemendag Perkuat Ekosistem E-Commerce dan Ekonomi Kreatif untuk Meningkatkan Daya Saing Produk Indonesia, Kemendag, Jakarta, hlm. 1.

B. Bawono Kristiaji, Asymmetric Information and Its Impact on Tax Compliance Cost in Indonesia: A Conceptual Approach, Tax Law Design and Policy Series, Vol. No. 0113, 2013, hlm. 4.

Organisation for Economic Co-operation and Development, 2014, Addressing the tax challenges of the digital economy, OECD Publishing, Paris, hlm. 34 . 
peristiwa (dalam hal ini transaksi elektronik) yang dapat menimbulkan utang pajak.

Kebocoran perpajakan karena kurangnya informasi akan semakin terlihat untuk suatu jenis pajak yang menggunakan system pemungutan self assessment dimana sistem ini adalah salah satu sistem pemungutan yang digunakan di Indonesia, hal ini disebabkan dalam sistem pemungutan tersebut wajib pajak yang dituntut untuk berperan aktif melaporkan segala aktivitas yang sekiranya dapat menimbulkan utang pajak kepada fiskus.

Penggunaan self assessment dalam pemungutan pajak menuntut kejujuran dan keterbukaan informasi dari wajib pajak sementara dalam transaksi elektronik maupun tranmisi data secara elektronik pada umumnya selalu memiliki peluang untuk timbul anonimitas dari para pihak yang terlibat, dengan demikian pada akhirnya ada tolak belakang antara kebijakan perpajakan yang menganut sistem self assessment dengan keadaan nyata di bidang teknologi informasi yang lebih dekat ke anonimitas.

Berangkat dari kontradiksi antara kebijakan self assessment dan sifat anonimitas dalam transaksi elektronik tersebut maka dapat ditekankan bahwa penelitian ini bertujuan untuk mencari konsep dalam mengumpulkan informasi perpajakan untuk transaksi elektronik yang sesuai dengan keadaan saat ini di Indonesia sehingga dapat ditarik pertanyaan penelitan sebagai berikut: (1) Bagaimanakah kebijakan perpajakan di Indonesia mengatur pertukaran informasi di sektor transaksi elektronik?; (2) Bagaimanakah instrumen hukum ideal yang diperlukan oleh fiskus untuk mengatasi asynchronous information?

\section{B. Metode Penelitian}

Penelitian ini bersifat yuridis normatif yaitu berupa pengumpulan bahan-bahan baik dari peraturan perundang-undangan, asas-asas hukum, doktrin serta sumber-sumber terkait lainnya yang berkaitan dengan pokok permasalahan secara mendalam.

Penelitian ini termasuk dalam penelitian kepustakaan, yaitu suatu penelitian yang bertujuan mendapatkan data sekunder dengan cara melakukan penelaahan terhadap peraturan perundangundangan, literatur, karya ilmiah di bidang hukum, dan bahan-bahan tertulis lainnya yang berkaitan dengan penelitian.

Analisis data yang diperoleh dari penelitian kepustakaan selanjutnya dianalisis secara kualitatif. Data yang terkumpul kemudian dikelompokkan dan dipilah-pilah dicari yang relevan dan representatif yang berhubungan dengan pokok permasalahan. Data tersebut selanjutnya dipelajari secara mendalam, ditelaah dan dipaparkan secara deskriptif, kemudian dibuat kesimpulan yang diharapkan dapat menjawab permasalahan yang diangkat dan dibahas tersebut.

\section{Hasil Penelitian dan Pembahasan}

1. Pengaturan Pertukaran Informasi dalam Kebijakan Perpajakan di Indonesia

Pada saat penelitian ini dilakukan pengaturan pertukaran informasi perpajakan secara umum telah diatur dalam beberapa kebijakan perpajakan di Indonesia yang antara lain Peraturan Pemerintah Pengganti Undang-Undang Nomor 1 Tahun 2017, Peraturan Menteri Keuangan - 70/PMK.03/2017 dan Peraturan Menteri Keuangan Republik Indonesia Nomor 73/PMK.03/2017 Tentang Perubahan Atas Peraturan Menteri Keuangan Nomor 70/ PMK.03/2017 Tentang Petunjuk Teknis Mengenai Akses Informasi Keuangan Untuk Kepentingan Perpajakan, substansi dari peraturan menteri tersebut terkait dengan kesiapan Indonesia dalam menghadapi Automatic Exchange of Information $(A E O I)$. Peraturan dipilih karena peraturan yang relevan dengan penelitian ini yaitu konsep dasar pertukaran informasi perpajakan dalam rangka meminimalisir dampak asynchronous information di bidang perpajakan.

a. Peraturan Pemerintah Pengganti Undang-Undang Nomor 1 Tahun 2017 tentang Akses Informasi Keuangan untuk Kepentingan 


\section{Perpajakan}

Peraturan pemerintah ini mengatur tentang pertukaran informasi keuangan secara otomatis untuk kepentingan perpajakan dengan tujuan utama untuk mematuhi ketentuan internasional di bidang perpajakan yang mengharuskan negara yang sudah terikat dengan perjanjian internasional tersebut memiliki peraturan yang mengatur cara pertukaran informasi secara otomatis. Tujuan dari dibuatnya peraturan ini sebenarnya adalah untuk memenuhi ketentuan perjanjian internasional yang diikuti oleh Indonesia yang menentukan bahwa Indonesia harus sudah mengimplementasikan peraturan tentang pertukaran informasi keuangan secara otomatis sebelum 30 Juni 2017.

Urgensi dari eksistensi peraturan tersebut sebenarnya terletak pada konsekuensi logis bagi Indonesia sebagai negara yang terikat dalam perjanjian internasional di bidang perpajakan. Adapun konsekuensinya apabila sampai dengan tanggal 30 Juni Indonesia belum memiliki peraturan tentang pertukaran informasi keuangan secara otomatis maka Indonesia akan dianggap gagal untuk memenuhi komitmen (fail to meet its commitment) yang mana lebih lanjut akan menurunkan kredibilitas Indonesia sebagai anggota G20.5 Dampak sistemik dari penurunan kredibilitas tersebut dapat mempengaruhi kepercayaan investor yang akan menanamkan modal di Indonesia yang lebih jauh lagi akan berpotensi mengganggu stabilitas ekonomi nasional serta dampak terburuknya adalah menjadikan Indonesia sebagai negara tujuan penempatan dana ilegal.

Secara substansi, pokok bahasan dalam Perpu ini masih sangat umum mengingat salah tujuan dari dibuatnya Perpu ini supaya Indonesia tidak dinyatakan gagal dalam memenuhi komitmen dalam perjanjian internasional yang akan membawa dampak yang signifikan bagi iklim usaha di Indonesia. Isu lain yang terkait dengan substansi Perpu ini adalah terkait dengan konten atau isi dari laporan keuangan secara otomatis yang sumbernya berasal dari lembaga jasa keuangan di sektor perbankan, pasar modal, asuransi atau entitas lain yang menurut perjanjian internasional di bidang perpajakan dikategorikan sebagai lembaga keuangan.

Berdasarkan analisis terhadap substansi dari Perpu tersebut maka dapat dikatakan bahwa Perpu tersebut memang terkait dengan pertukaran informasi keuangan di bidang perpajakan namun pertukaran secara otomatis tersebut tidak mencakup isu spesifik seperti yang dirumuskan dalam penelitian ini, yaitu terkait dengan asynchronous information yang terjadi dalam transaksi elektronik.

Materi muatan Perpu ini lebih menitikberatkan sebagai suatu bentuk kepatuhan terhadap perjanjian internasional yang mengikat bagi Indonesia untuk segera memiliki peraturan perpajakan yang mengatur pertukaran informasi keuangan secara otomatis, terlebih dalam pelaksanaanya Perpu ini membutuhkan peraturan teknis yang berbentuk Peraturan Menteri Keuangan (PMK) .

Secara umum cakupan dalam Perpu ini dapat dijelaskan sebagi berikut: ${ }^{6}$

a. Tujuan dan cakupan akses informasi;

b. Pihak yang berhak mendapatkan akses informasi dan wajib memberikan akses informasi;

c. Substansi laporan informasi

Bagian menimbang huruf c Peraturan Pemerintah Pengganti Undang-Undang Nomor 1 Tahun 2017 tentang Akses Informasi Keuangan Untuk Kepentinga Perpajakan.

Lihat judul Bab dalam Peraturan Pemerintah Pengganti Undang-Undang Nomor 1 Tahun 2017 tentang Akses Informasi Keuangan Untuk Kepentingan Perpajakan. 
keuangan;

d. Prosedur identifikasi terhadap informasi di bidang keuangan yang akan dilaporkan;

e. Pembuatan dokumentasi dalam bahasa Indonesia;

f. Tidak berlakunya kerahasiaan di bidang keuangan untuk informasi keuangan yang wajib diberikan kepada pihak yang berhak dalam konteks $A E O I$;

g. Mekanisme penyampaian informasi keuangan;

h. Kewenangan fiskus untuk mendapat informasi lebih jauh terkait dengan laporan yang telah disampaikan;

i. Penjelasan bahwa informasi yang diperoleh di yurisdiksi Indonesia akan disampaikan oleh menteri keuangan ke pihak berwenang di yurisdiksi yang lain;

j. Ketentuan perlindungan hukum bagi aparat yang melakukan tugas yang terkait dengan hal ini;

k. Ancaman pidana bagi pihak yang wajib melaporkan apablia tidak memenuhi ketentuan dalam peraturan;

1. Ketentuan yang menyebutkan bahwa peraturan lain yang mengatur tentang kerahasiaan data menjadi tidak berlaku sepanjang digunakan untuk kepentigan yang terkait dengan akses informasi keuangan terkait AeoI.

Berkaitan dengan asynchronous information yang terjadi dalam transaksi elektronik di Indonesia maka Perpu ini secara umum hanya dapat menjelaskan bahwa pertukaran data secara otomatis dengan menggunakan teknologi informasi dapat dilakukan, namun demikian apabila objeknya adalah tentang asynchronous information yang terjadi dalam transaksi elektronik di Indonesia maka Perpu ini tidak akan dapat menjangkau ketimpangan data antara fiskus dan wajib pajak yang melakukan transaksi elektronik. Kekurangan yang ada dalam Perpu disebabkan antara lain karena Pengaturan pihak yang dapat melakukan laporan atau memberikan informasi secara otomatis adalah lembaga jasa keuangan yang kegiatannya seputar sektor perbankan, pasar modal, asuransi serta entitas lainnya yang dapat dikategorikan sebagai lembaga keuangan serta berbentuk badan hukum. Selain itu, pihak yang dilaporkan (pihak yang informasinya diambil oleh fiskus) merupakan orang pribadi atau entitas yang negara domisilinya merupakan yurisdiksi tujuan pelaporan, dengan demikian pelaporan atau pertukaran informasi ini berlaku untuk warga negara atau entitas asing (bukan Indonesia).

b. Peraturan Menteri Keuangan - 73/ PMK.03/2017 tentang Petunjuk Teknis Mengenai Akses Informasi Keuangan untuk Kepentingan Perpajakan

Substansi peraturan ini adalah untuk melaksanakan ketentuan yang telah diatur dalam Perpu No. 1 Tahun 2017, kedudukan PMK untuk saat ini adalah sebagai perubahan atas PMK No. 70/PMK.03/2017. Sebagai peraturan pelaksana dari Perpu No. 1 Tahun 2017 PMK ini mengatur lebih detil mengenai beberapa hal yang terkait dengan pertukaran informasi keuangan secara otomatis.

Dalam PMK ini salah satu hal yang spesifik adalah klasifikasi mengenai pihak yang harus dilaporkan data dan atau informasinya oleh penyedia jasa keuangan kepada fiskus (dalam hal ini Menteri Keuangan). Berikut kerangka logis 
berdasarkan peraturan ini:

Tabel 1.

Klasifikasi Pihak yang Datanya Harus Dilaporkan oleh Penyedia Jasa Keuangan kepada Fiskus

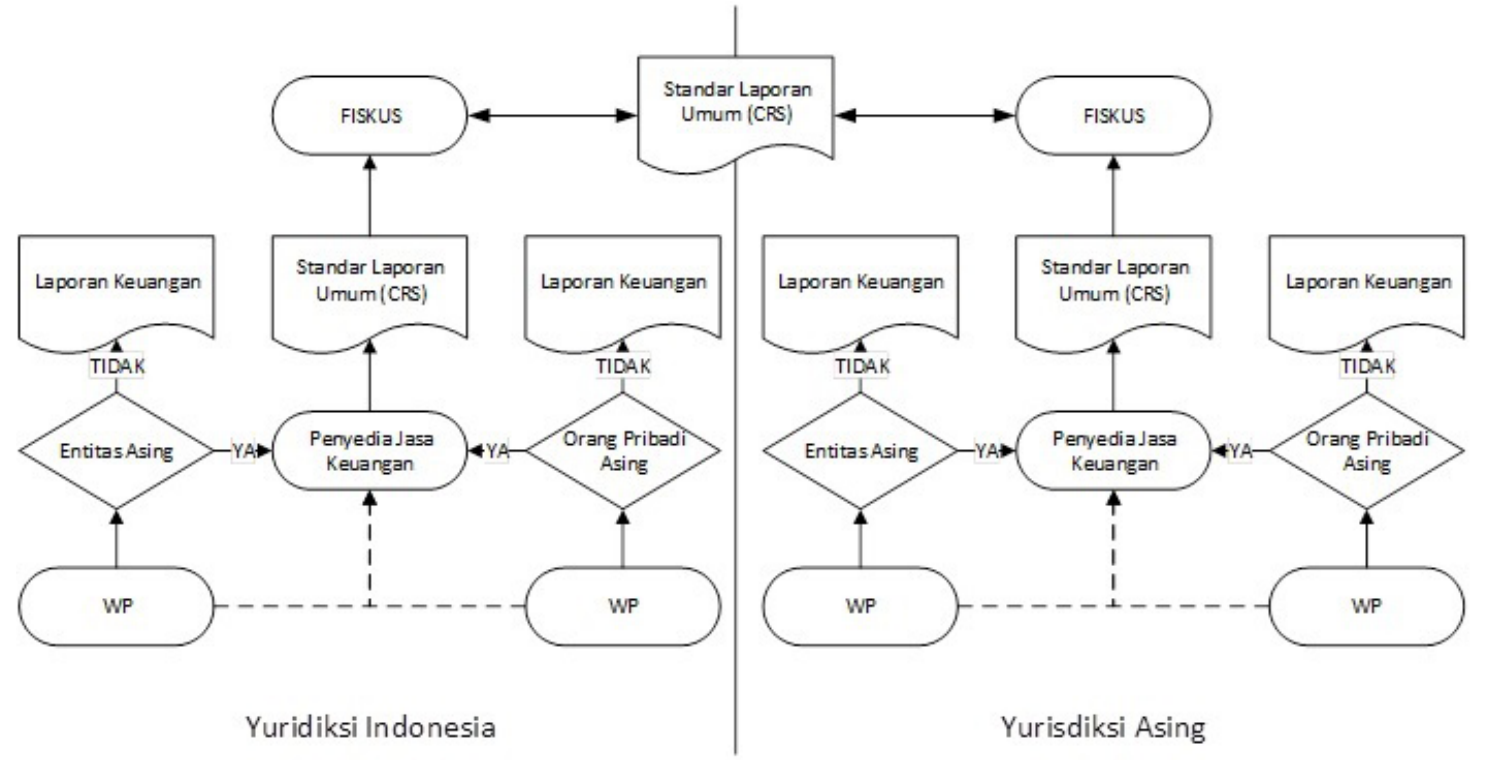

Sumber : PMK 73/PMK.03/2017

Tabel tersebut menjelaskan bahwa data dan atau informasi yang diperoleh oleh fiskus berasal dari penyedia jasa keuangan sebagaimana diatur dalam PMK 73/PMK.03/2017, adapun kriteria supaya standar laporan umum atau common reporting standard (CRS) dapat terjadi maka harus ditentukan terlebih dahulu apakah orang pribadi atau entitas pengguna jasa keuangan ini merupakan pihak asing atau tidak. Laporan yang disampaikan oleh LJK kepada fiskus hanya terjadi apabila orang pribadi atau entitas pengguna jasa keuangan tersebut merupakan pihak asing.

Penjelasan lain yang menyatakan bahwa yang wajib dilaporkan data dan atau informasi keuangannya terdapat dalam Surat Edaran Otoritas Jasa Keuangan Nomor 16/SEOJK.03/2017 tentang Penyampaian Informasi Nasabah Asing Terkait Perpajakan
Dalam Rangka Pertukaran Informasi Secara Otomatis Antar Negara Dengan Menggunakan Standar Pelaporan Bersama (Common Reporting Standard). Dalam surat edaran tersebut dijelaskan bahwa yang wajib untuk dilaporkan adalah nasabah asing ${ }^{7}$ sedangkan pihak yang wajib melaporkan adalah: bank umum, bank umum syariah, perusahaan efek, bank kustodian, perusahaan asuransi jiwa dan perusahaan asuransi jiwa syariah. Apabila dikaitkan dengan asynchronous information yang terjadi dalam transaksi elektronik maka peraturan ini hanya mencakup secara parsial. Penyebab cakupan parsial ini tidak lain karena kedudukan penyedia jasa keuangan yang harus di Indonesia sementara untuk pengguna layanan jasa keuangannya harus orang pribadi atau entitas asing.

Kekurangan informasi ${ }^{8}$ yang dimiliki fiskus untuk transaksi elektronik yang

Bagian III angka 1, Surat Edaran Otoritas Jasa Keuangan Nomor 16/SEOJK.03/2017 Tahun 2017 tentang Penyampaian Informasi Nasabah Asing Terkait Perpajakan Dalam Rangka Pertukaran Informasi Secara Otomatis Antarnegara Dengan Menggunakan Standar Pelaporan Bersama (Common Reporting Standard).

Menggunakan konsep AEoI untuk melakukan pengumpulan informasi terkait dengan transaksi elektronik di Indonesia memiliki keterbatasan karena hukum positif mengenai $A E O I$ telah menentukan bahwa objek pelaporan dalam format standar $(C R S)$ adalah warga negara asing dengan 
dilakukan oleh WNI (bukan subjek pelaporan sebagaimana ditentukan dalam perjanjian internasional) akan bertambah parah karena penggunaan sistem self assessment. ${ }^{9}$ Hal tersebut dapat terjadi karena dalam sistem self assessment pelaku transaksi elektronik yang berperan aktif untuk melaporkan informasi perpajakan sementara itu faktor administrasi pelaporan pajak di Indonesia yang tidak sederhana (rumit) ${ }^{10}$ menjadi kendala tersendiri bagi pelaku transaksi elektronik untuk menyampaikan laporan perpajakannya.

Kompleksitas dalam aturan dan sistem pelaporan perpajakan tersebut akan berpengaruh terhadap tingkat kepatuhan dari wajib pajak ${ }^{11}$ dengan kompleksitas yang tinggi di bidang perpajakan maka tingkat kepatuhan perpajakan pelaku transaksi elektronik akan rendah. Dengan rendahnya tingkat kepatuhan dapat diartikan bahwa fiskus tidak mendapatkan informasi perpajakan yang terkait dengan transaksi elektronik secara maksimal khsusnya terhadap pajak yang timbul atas transaksi elektronik dan menggunakan sistem self assessment yaitu PPN dan PPh.

\section{Instrumen Hukum Ideal yang Diperlukan oleh Fiskus untuk Mengatasi Asynchronous Information}

Berdasarkan analisis yang ada pada sub bab sebelumnya dapat disimpulkan bahwa sebenarnya Indonesia memang belum memiliki instrumen hukum yang secara spesifik mengatasi dampak dari asynchronous information yang terjadi dalam transaksi elektronik. Meskipun Indonesia telah memiliki Peraturan Pemerintah Pengganti UndangUndang Nomor 1 Tahun 2017 tentang Akses Informasi Keuangan Untuk Kepentingan Perpajakan peraturan tersebut lebih menekankan pada kepatuhan Indonesia pada perjanjian internasional yang terkait dengan $A E O I$ sehingga sasaran data perpajakan yang akan diambil informasinya adalah orang pribadi atau entitas asing yang memiliki informasi keuangan di Indonesia.

Berdasarkan perbandingan dengan negara terdekat yaitu Singapura, negara tersebut telah mengatur secara rinci perpajakan untuk sektor perdagangan secara elektronik. Pengaturan tersebut terkait dengan cara menentukan transaksi elektronik yang dapat dikenakan pajak sesuai dengan yurisdiksi Singapura. Menurut ketentuan perpajakan untuk transaksi elektronik di Singapura dijelaskan bahwa untuk melakukan klasifikasi apakah pihak yang melakukan transaksi tunduk pada yurisdiksi perpajakan Singapura atau tidak adalah dengan menggunakan internet protocol address $^{12}$ (IP address).

Aspek lain dari substansi peraturan perpajakan di Singapura adalah penggunaan sistem pemungutan yang sama dengan di Indonesia yaitu self assessment system. Penggunaan self assessment tersebut terlihat dari subtansi peraturan perpajakan Singapura terkait dengan transaksi elektronik yang banyak menjelaskan mengenai kewajiban pelaku usaha untuk melaporkan sendiri bahwa yang bersangkutan telah melakukan suatu perbuatan yang menimbulkan utang pajak atau tidak. Dalam panduan terkait dengan perpajakan untuk transaksi elektronik di Singapura juga telah dijelaskan bahwa pihak yang terlibat dalam transaksi elektronik wajib untuk memiliki catatan (log, record keeping) terkait dengan transaksi yang telah dilakukan. ${ }^{13}$

demikian warga negara Indonesia bukan merupakan pihak yang harus dilaporkan.

Sistem pemungutan self asssessment menuntut kepatuhan dari wajib pajak karena pada pihak tersebutlah dibebankan kewajiban untuk menghitung dan melaporkan pajak yang terutang.

10 Deloitte, 2017, Shifting sands: risk and reform in uncertain times 2017 Asia Pacific Tax Complexity Survey, Deloitte Touche Tohmatsu Limited, London, hlm. 9.

11 Ibid.

12 IP Address adalah alamat komputer atau peralatan jaringan yang terhubung dalam suatu jaringan (intranet atau internet), alamat komputer ini digunakan sebagai identitas komputer dan dapat digunakan untuk menentukan lokasi secara geografis komputer tersebut (geolocation).

13 Inland Revenue Authority of Singapore, 2017, Record Keeping Guide for GST-Registered Businesses, Inland Revenue Authority of Singapore, Singapore, hlm. 1 . 
Kemudian terkait dengan isu yang lebih spesifik yaitu terkait dengan asynchronous information dalam perdagangan elektronik, peraturan di Singapura tidak atau belum mengatur secara spesifik. Namun demikian meski samasama tidak memiliki peraturan yang spesifik untuk mengatasi asynchronous information yang terjadi dalam perdagangan elektronik Singapura memiliki tax ratio yang lebih tinggi dibandingkan Indonesia ${ }^{14}$

Perbedaan tax ratio antara Singapura dan Indonesia sebagaimana telah dijelaskan diatas memberikan alasan pentingnya Indonesia memiliki instrumen hukum terkait dengan pemungutan pajak untuk perdagangan elektronik. Sebagai gambaran untuk saat ini instrumen hukum yang telah ada $^{15}$ memiliki objek berbeda dengan objek yang menjadi fokus dalam penelitian ini yaitu pertukaran informasi untuk setiap orang pribadi di Indonesia yang melakukan transaksi elektronik di Indonesia. Selain terdapat perbedaan yang signifikan dalam objek terdapat pula perbedaan dalam siapa yang harus memberikan informasi terkait dengan perpajakan, dalam instrumen hukum yang sudah ada pihak yang wajib memberikan laporan adalah pihak yang bergerak di bidang jasa keuangan dan yang dipersamakan dengan jasa keuangan.

Konsep yang diusung dalam penelitian ini mempertimbangkan secara logis dari aliran data dan atau informasi yang terjadi dalam transaksi. Untuk melihat isu yang berbeda dengan para pihak yang terlibat dalam transaksi elektronik dapat digambarkan dalam bagan berikut: ${ }^{16}$

Tabel 2.

\section{Aliran Data atau Informasi dalam Transaksi Elektronik}

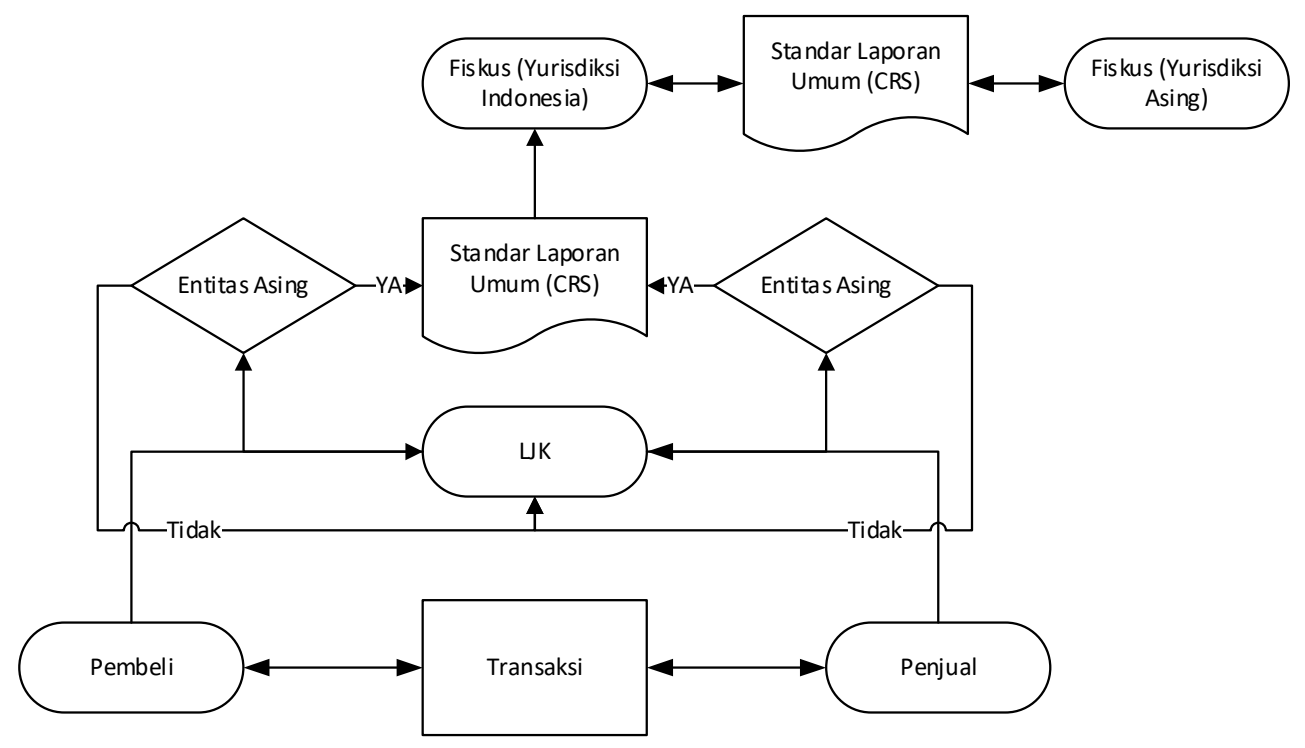

Sumber : Diolah Penulis, 2017.

Diagram alir tersebut menjelaskan bahwa fiskus hanya akan mendapatkan data dan atau informasi mengenai penjual maupun pembeli dalam transaksi elektronik apabila pihak penjual atau pembeli merupakan pihak yang data dan atau informasi keuangannya wajib dilaporkan oleh penyedia jasa keuangan yang mana berdasarkan Perpu No. 2017 dan PMK sebagai petunjuk teknisnya adalah orang pribadi atau entitas asing yang memiliki data dan atau informasi keuangan yang disimpan oleh penyedia jasa keuangan di Indonesia. Berdasarkan analisis tersebut maka

\footnotetext{
4 World Bank, "Tax Revenue GDP", https://data.worldbank.org/indicator/GC.TAX.TOTL.GD.ZS?year high desc=false diakses 10 Oktober 2017.

15 Lihat Perpu No.1 Tahun 2017 dan Peraturan Teknis petunjuk pelaksanaannya.

16 Piotr Stolarski, et al., 2008, Legal Framework for eCommerce Tax Analysis, Springer US, Boston, hlm. 444-445.
} 
dapat disimpulkan:

a. Apabila pembayaran tidak menggunakan penyedia jasa keuangan di Indonesia maka fiskus tidak akan mendapat data dan atau informasi yang lengkap.

b. Apabila pihak yang melakukan transaksi adalah warga negara Indonesia maka fiskus tidak mendapat data dan atau informasi karena penyedia jasa keuangan tidak wajib untuk melaporkan pemilik rekening yang bukan orang pribadi atau entitas asing (data dan atau informasi keuangan yang wajib dilaporkan adalah milik orang pribadi atau entitas asing)

Penggunaan konsep pertukaran informasi yang sudah ada dalam AeoI yang diatur dalam Perpu
No. 1 Tahun 2017 tidak dapat diimplementasikan begitu saja untuk transaksi elektronik, penggunaan konsep yang sudah ada mengakibatkan masih terdapat asynchronous information dan dengan demikian bukan solusi terbaik.

\section{a. Menggunakan Konsep Dalam AEoI}

Solusi mengatasi kekurangan terhadap informasi yang diperoleh oleh fiskus dalam hal transaksi elektronik tentang kewajiban perpajakan para pihak (penjual dan pembeli) adalah tetap menggunakan instrumen hukum yang telah ada sebagai basisnya. Solusi ini dipilih karena dapat dilakukan dengan memanfaatkan instrumen maupun infrastruktur yang diciptakan untuk AeoI.

Berikut adalah diagram alir terhadap proses pertukaran informasi dengan menggunakan Perpu No. 1 Tahun 2017 sebagai dasarnya:

Tabel 3.

Proses Pertukaran Informasi Berdasarkan Perpu No. 1 Tahun 2017

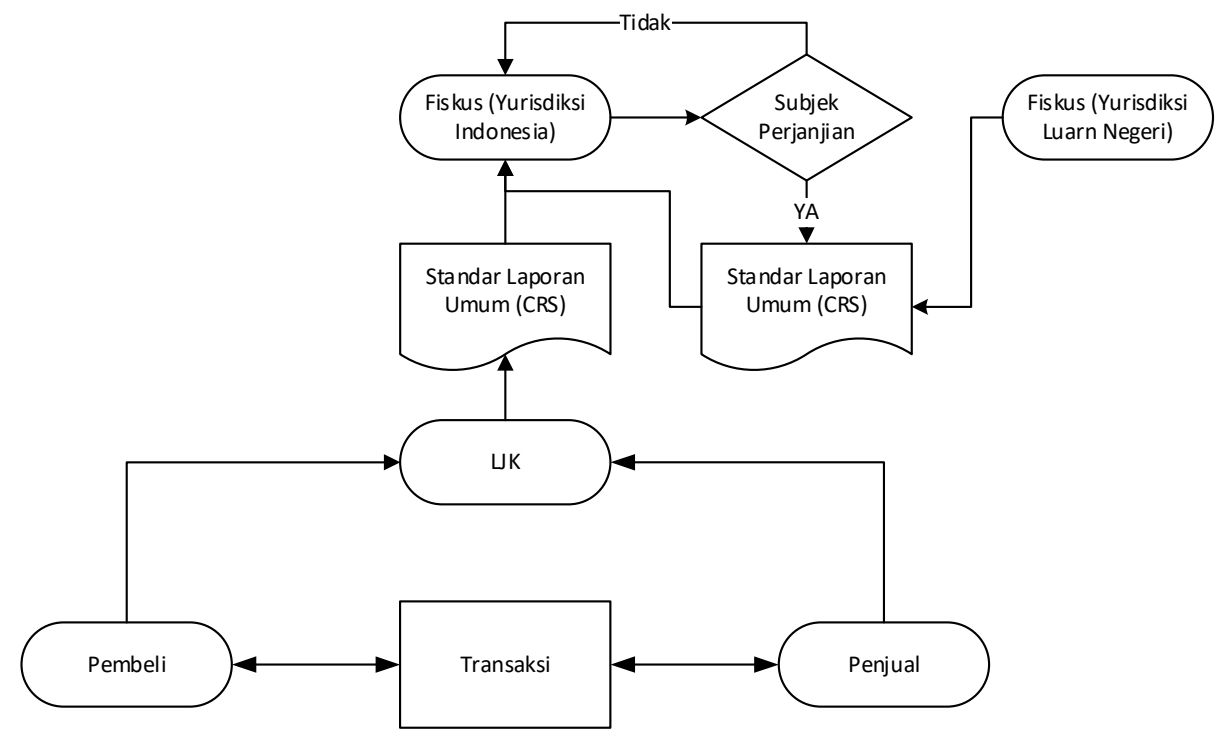

Sumber : Perpu Nomor 1 Tahun 2017.

Diagram alir tersebut menjelaskan bahwa fiskus akan mendapatkan data dan atau informasi mengenai penjual maupun pembeli dalam transaksi elektronik siapapun pihak yang melakukannya, informasi dan atau data akan diambil baik untuk pihak yang merupakan orang dan atau entitas luar maupun dalam negeri. Berdasarkan analisis tersebut maka dapat disimpulkan

a. apabila pembayaran tidak menggunakan penyedia jasa keuangan di Indonesia maka fiskus tidak akan 
mendapat data dan atau informasi yang lengkap.

b. Fiskus akan mendapatkan data untuk setiap informasi dan atau data keuangan yang dilakukan dengan menggunakan penyedia jasa keuangan yang berkedudukan di Indonesia.

c. Apabila pihak yang melakukan transaksi adalah warga negara Indonesia maka fiskus akan mendapat data dan atau informasi yang mana hal ini berbeda dengan skenario sebelumnya.

Prinsip utama dalam skenario ini supaya fiskus mendapatkan informasi terkait denan transaksi elektronik tersebut adalah kedudukan dari penyedia jasa keuangan yang harus berkedudukan di Indonesia.

\section{b. Konsep Ideal}

Konsep ideal untuk mengatasi ketimpangan informasi ini adalah dengan menggunakan sistem self assessment sebagai upaya untuk mengatasi asynchronous information yang terjadi dalam transaksi elektronik. Dengan menggunakan pelaporan yang dibuat oleh masing-masing pihak yang bertransaksi maka fiskus akan mendapatkan data dan atau informasi yang lebih menyeluruh mengenai aspek perpajakan yang timbul dalam suatu transaksi elektronik.

Penggunaan model ini akan memberikan informasi kepada fiskus mengenai transaksi elektronik yang dilakukan oleh penjual dan pembeli, informasi yang diperoleh fiskus hanya akan diperoleh apabila perbuatan jual beli yang dilakukan oleh penjual dan pembeli tersebut termasuk dalam perbuatan yang menyebabkan timbulnya utang pajak. Untuk mengetahui jenis transaksi tersebut termasuk perbuatan yang menyebabkan timbulnya utang pajak atau tidak fiskus harus mendapatkan data dan atau informasi perpajakan dari para pihak yang terlibat dengan cara pelaporan self assessment. Berikut diagram alir konsep tersebut:

Tabel 4.

\section{Konsep Ideal Mengatasi Ketimpangan Informasi dalam Transaksi Elektronik}

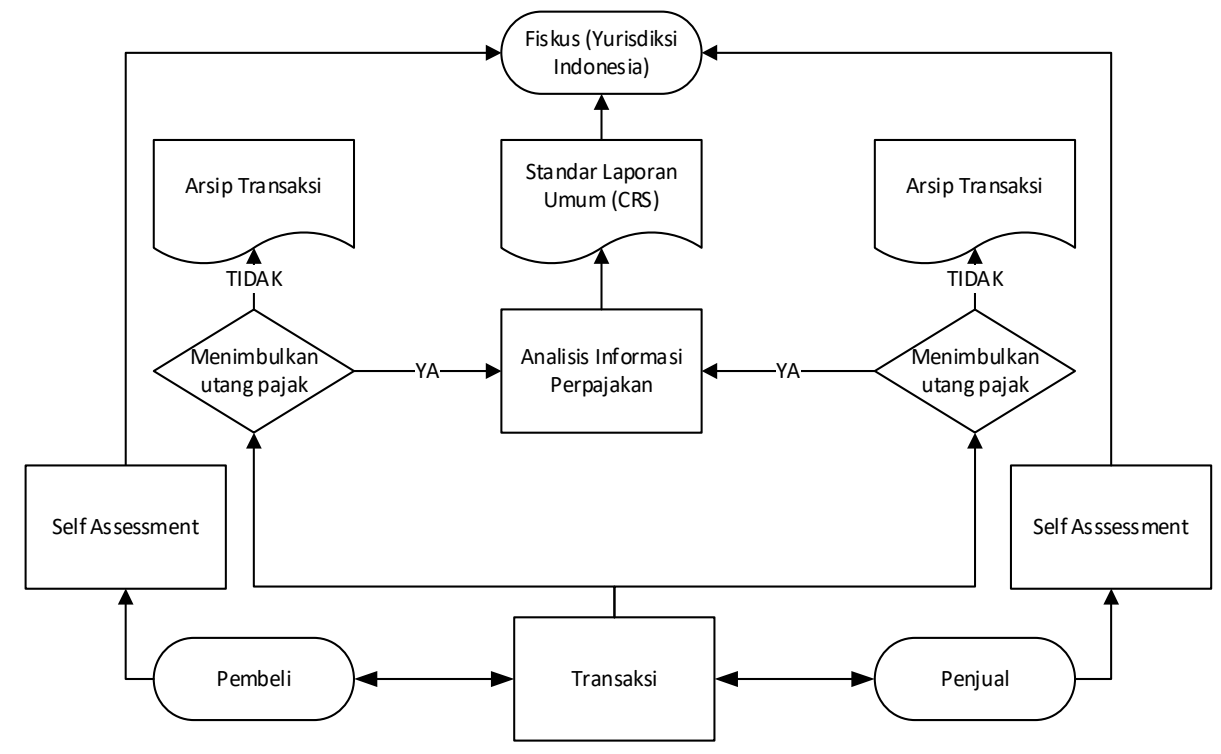

Sumber : Diolah Peulis, 2017.

Penggunaan model ini memastikan fiskus akan mendapatkan informasi tentang jumlah utang pajak yang timbul dari transaksi elektronik tersebut. Namun penggunaan 
model ini juga memiliki kelemahan karena adanya unsur self assessment, penggunaan self assessment menuntut adanya kejujuran dari para pihak untuk melaporkan. Meski terdapat kelemahan sebagaimana telah dijelaskan sebelumnya sistem ini tetap dapat

Tabel 5.

\section{Penerapan Konsep Ideal Transaksi Elektronik yang Tidak Melalui Penyedia Jasa}

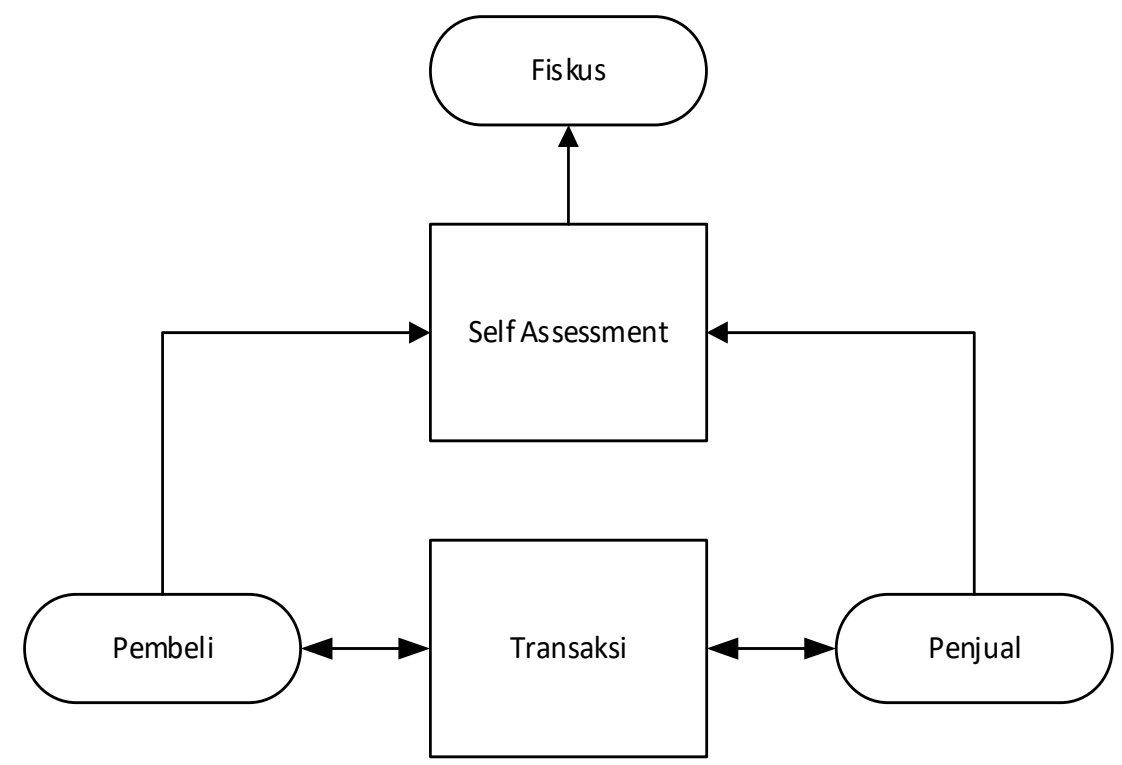

Sumber : Diolah Penulis, 2017.

Diagram tersebut menjelaskan bahwa pihak penjual dan pembeli tidak menggunakan sistem yang disediakan oleh penyedia layanan (pihak ke-3) ${ }^{17}$, pada transaksi yang seperti ini para pihak yang terlibat transaksi yang memiliki informasi paling lengkap sedangkan pihak fiskus tidak mendapatkan informasi telah terjadi suatu perbuatan yang menimbulkan utang pajak. Untuk model transaksi ini fiskus hanya akan mengetahui telah timbul perbuatan yang menimbulkan utang pajak apabila para pihak melaporkan perbuatan yang mereka lakukan, sehingga tanpa adanya laporan dari para digunakan untuk transaksi elektronik yang menggunakan pihak ke-3 sebagai penyedia jasanya. Berikut adalah contoh ketika konsep ideal diterapkan untuk transaksi elektronik yang tidak melalui pihak penyedia jasa: 
Tabel 6.

\section{Penerapan Konsep Ideal Transaksi Elektronik yang Melibatkan Pihak Ketiga}

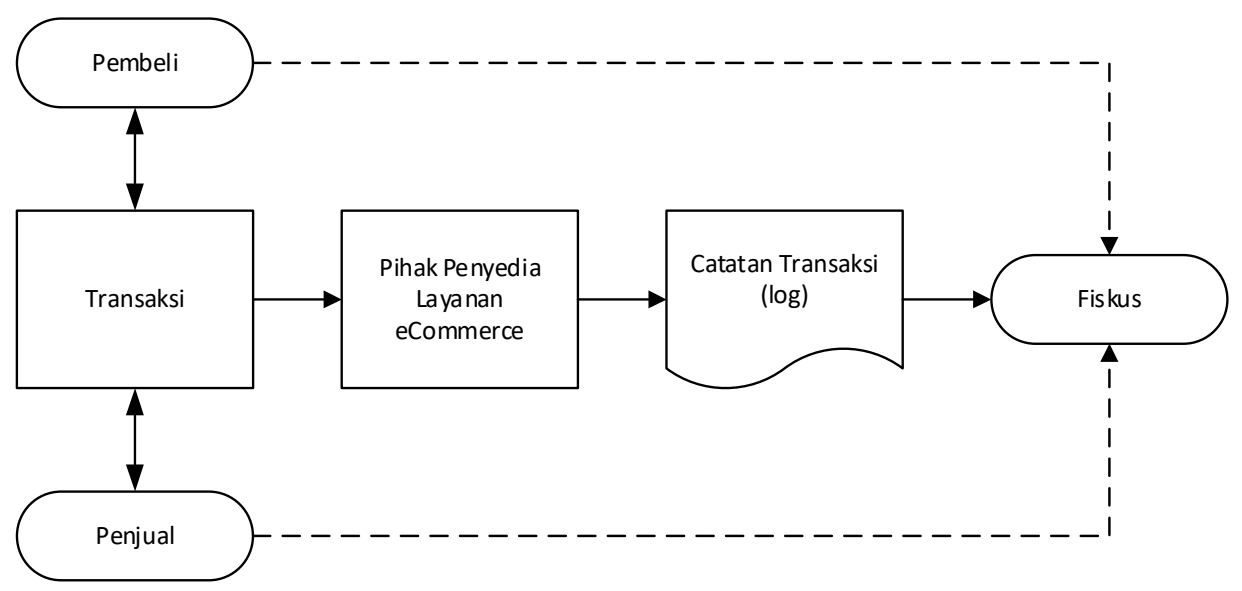

Sumber : Diolah Penulis, 2017.

Dalam tabel tersebut menggunakan pihak ke-3 sebagai penyedia layanan transaksi elektronik sehingga meskipun para pihak transaksi tidak melaporkan secara self assessment kepada fiskus disini masih terdapat dokumen yang menjelaskan telah terjadi transaksi dan dokumen yang berasal dari pihak ke-3 dalam transaksi inilah yang akan menjadi sumber data dan atau informasi bagi fiskus.

\section{c. Konsep Ideal Ekstensif}

Konsep ini hampir sama dengan konsep ke-2, hanya saja dalam konsep fiskus akan selalu memperoleh informasi yang sama dengan para pihak yang melakukan transaksi elektronik. Berikut adalah data flow untuk konsep ini:

Tabel 7.

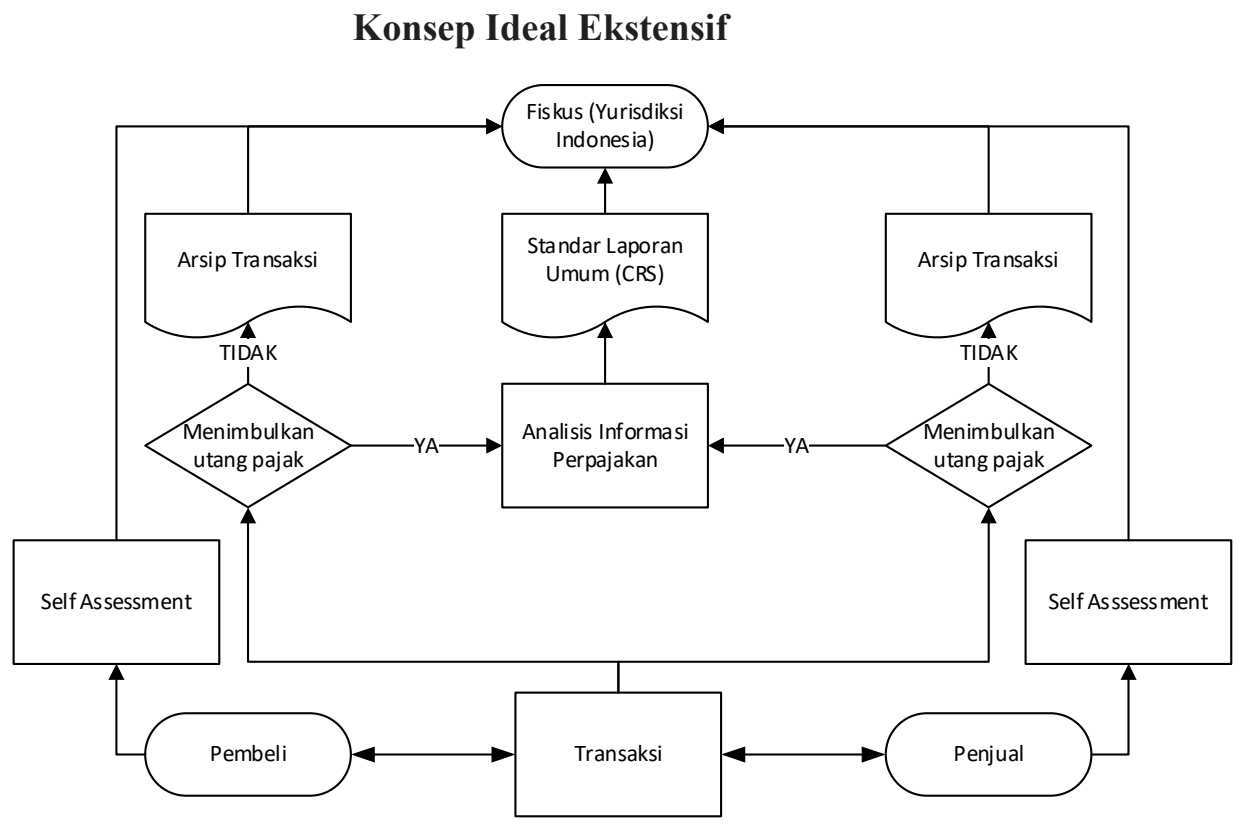

Sumber : Diolah Penulis, 2017.

Berdasarkan diagram alir tersebut maka kriteria semua transaksi baik yang menimbulkan utang pajak maupun yang tidak akan tercatat dan diketahui oleh fiskus, 
dengan demikian asynchronous information menjadi tidak ada. Meski asynchronous information yang terjadi dalam transaksi elektronik telah tereliminasi konsep ini tetap membutuhkan kriteria yang sama dengan konsep sebelumnya (konsep ideal) yaitu tetap terdapat dependensi dengan pihak ke-3 yang menyediakan sistem informasi untuk transaksi elektronik. Tanpa adanya pihak ke-3 maka tetap akan muncul kendala dalam hal data atau informasi yang akan diterima oleh fiskus. ${ }^{18}$

\section{d. Pemilihan Konsep}

Berdasarkan beberapa konsep yang telah ditawarkan dapat dijelaskan bahwa konsep pertama adalah dengan meminjam konsep yang ada dalam peraturan yang mengatur AeoI, penggunaan konsep ini memungkinkan terjadinya minimalisir asynchronous information hanya untuk kondisi dimana pihak yang melakukan transaksi menggunakan penyedia jasa keuangan yang berkedudukan di Indonesia dan pihak dalam transaksi tersebut adalah pihak asing.

Konsep kedua atau dalam penelitian ini disebut dengan konsep ideal adalah penyesuaian yang berdasarkan konsep sebelumnya hanya saja dalam konsep ini tidak menuntut yang melakukan transaksi adalah pihak asing sedangkan untuk kriteria lainnya terkait dengan informasi yang akan diperoleh oleh fiskus adalah jenis transaksinya, apabila transaksinya merupakan suatu peristiwa yang menyebabkan timbulnya utang pajak maka fiskus akan mendapatkan data dan atau informasi atas transaksi tersebut serta berlaku pula sebaliknya apabila transaksi tersebut bukan suatu perbuatan yang menimbulkan utang pajak maka fiskus tidak akan memperoleh data dan atau informasi terkait dengan transaksi elektronik tersebut.
Konsep ketiga adalah konsep ideal ekstensif yang serupa dari konsep sebelumnya namun dengan kriteria yang lebih longgar, yaitu tanpa adanya syarat atau kondisi perbuatan yang menimbulkan utang pajak. Dengan kondisi ini setiap transaksi selain diketahui para pihak yang secara langsung terlibat juga akan diketahui oleh fiskus.

Dari beberapa konsep yang ditawarkan tersebut, konsep kedua dapat mengeliminasi asynchronous information secara parsial sedangkan konsep ketiga dapat menghilangkan sama sekali asynchronous information. Namun demikian kedua konsep tersebut tetap memiliki kelemahan di luar aspek perpajakan yaitu dibutuhkannya pihak ke-3 sebagai penyedia sistem elektronik yang akan digunakan untuk melakukan transaksi elektronik, tanpa adanya pihak ke-3 maka baik konsep ke-2 maupun konsep ketiga tidak akan dapat berjalan dengan baik.

Sedangkan konsep yang mungkin diterapkan dengan memperhatikan keadaan di Indonesia yang terkait dengan peraturan dan sistem pelaporan perpajakan, maka konsep ketiga yang paling mungkin untuk diterapkan. Penggunaan konsep ini tidak terlalu bergantung kepada informasi yang harus dikirimkan oleh pelaku transaksi elektronik sehingga beban pelaku transaksi elektronik untuk memberikan informasi perpajakan kepada fiskus akan lebih ringan.

\section{Kesimpulan}

1. Pengaturan tentang pertukaran informasi secara elektronik di Indonesia untuk saat diatur dalam Perpu No. 1 Tahun 2017 tentang Akses Informasi Keuangan Untuk Kepentingan Perpajakan beserta peraturan teknisnya yaitu Peraturan Menteri Keuangan Nomor 73/ 
PMK.03/2017 Tahun 2017 tentang Tentang Petunjuk Teknis Mengenai Akses Informasi Keuangan Untuk Kepentingan Perpajakan. Pengaturan pertukaran informasi tersebut dibuat sebagai bentuk kepatuhan Indonesia terhadap perjanjian internasional di bidang AeoI yang pada dasarnya tidak mencakup suatu cara untuk mengatasi timbulnya asynchronous information dalam transaksi elektronik. Dengan demikian apabila kita kaitkan kembali dengan isu asynchronous information di bidang transaksi elektronik maka sebenarnya Indonesia belum memiliki kebijakan secara konkrit.Kebijakan yang ada untuk saat ini hanya sebatas pada konsep bahwa dimungkinkan bagi fiskus untuk mendapat informasi terkait perpajakan dengan cara elektronik.

2. Instrumen hukum ideal untuk mengatasi permasalah terkait dengan asynchronous information dalam transaksi elektronik memiliki beberapa opsi yang terdiri dari 3 konsep yaitu: dengan menggunakan konsep yang telah ada dalam AeoI, konsep ideal dan konsep ideal ekstensif. Dari beberapa pilihan tersebut khususnya dengan mempertimbangkan kompleksitas peraturan dan pelaporan pajak di Indonesia maka konsep yang mungkin untuk diterapkan adalah konsep ideal ekstensif (konsep ke-3) karena dengan menggunakan konsep ini maka beban untukmelaporkaninformasiperpajakan bagi pelaku transaksi elektronik untuk memberikan informasi kepada fiskus menjadi lebih ringan dan bagi pihak fiskus akan terbantu dengan adanya otomatisasi dalam pengumpulan data melalui sistem elektronik.

\section{DAFTAR PUSTAKA}

\section{A. Buku}

Deloitte, 2017, Shifting sands: risk and reform in uncertain times 2017 Asia Pacific Tax Complexity Survey, Deloitte Touche Tohmatsu Limited, United Kingdom

Inland Revenue Authority of Singapore, 2017, Record Keeping Guide for GST-Registered Businesses, Inland Revenue Authority of Singapore, Singapore.

Kemendag, 2016, Kemendag Perkuat Ekosistem E-Commerce dan Ekonomi Kreatif
untuk Meningkatkan Daya Saing Produk
Indonesia,Kemendag, Jakarta. Organisation for Economic Co-operation and Development, 2014, Addressing the tax challenges of the digital economy, OECD Publishing, Paris

Piotr Stolarski, et al., 2008, Legal Framework for eCommerce Tax Analysis, Springer US, Boston.

\section{B. Artikel Jurnal}

Kristiaji, B. Bawono, Asymmetric Information and Its Impact on Tax Compliance Cost in Indonesia: A Conceptual Approach, Tax Law Design and Policy Series, Vol. No. 0113, 2013.

\section{Peraturan Perundang-Undangan}

Peraturan Pemerintah Pengganti Undang-Undang Nomor 1 Tahun 2017 tentang Akses Informasi Keuangan Untuk Kepentingan Perpajakan (Lembaran Negara Republik Indonesia Tahun 2017 Nomor 95, Tambahan Lembaran Negara Republik Indonesia Nomor 6051). 
Surat Edaran Otoritas Jasa Keuangan Nomor 16/

SEOJK.03/2017 Tentang Penyampaian Informasi Nasabah Asing Terkait Perpajakan Dalam Rangka Pertukaran Informasi Secara Otomatis Antar Negara Dengan Menggunakan Standar Pelaporan Bersama (Common Reporting Standard).

\section{Internet}

Kompas, "Pengguna Internet di Indonesia Capai 132 juta", http://tekno.kompas.com/ read/2016/10/24/15064727/2016.pengguna. internet.di.indonesia.capai.132.juta., diakses pada 1 April 2017.

World Bank, "Tax Revenue GDP”, https://data. worldbank.org/indicator/GC.TAX.TOTL. GD.ZS? year high desc $=$ false diakses 10 Oktober 2017. 